\title{
E. coli-Based In Vitro Transcription/Translation: In Vivo-Specific Synthesis Rates and High Yields in a Batch System
}

BioTechniques 24:862-868 (May 1998)

\author{
Ranjan Patnaik and James R. \\ Swartz \\ Genentech, South San \\ Francisco, CA, USA
}

\section{INTRODUCTION}

E. coli-based transcription/translation systems have been used for several decades and recently have been applied to: $(i)$ expression of toxic rDNA proteins, (ii) radiolabeling of newly synthesized gene products, (iii) incorporation of unnatural amino acids and (iv) production of small quantities of proteins quickly and economically $(5,7,12$, 19). Summaries of various other applications as well as accounts of batch system development have been reported $(5,10,18,23,24)$. Most notable is the recent report of Kim et al. (11). By using condensed cell extracts and optimized concentrations of polyethylene glycol and phosphoenol pyruvate and by adding more amino acids, they were able to synthesize $0.4 \mathrm{mg} / \mathrm{mL}$ of chloramphenical acetyltransferase (CAT) in a batch reaction. Continuous, cell-free protein synthesis systems also have been described by several groups and offer extended synthesis periods but are more complex to operate and also have higher reagent costs $(1,9,22)$.

More recently, an intermediate approach has been developed by Kim and Choi (10). Using a semicontinuous approach, they conducted the synthesis reaction in a chamber bounded by a dialysis membrane to allow interchange with a larger reservoir $(25 \times$ volume $)$ of low-molecular-weight reagents. During a 14-h reaction, $1.2 \mathrm{mg} / \mathrm{mL}$ of CAT accumulated in the smaller reaction chamber.

In an attempt to produce a simple and productive batch system, we have independently improved the methods of Pratt (19) and Zubay (27) to increase initial, specific synthesis rates as well as the duration of synthesis. We report a batch system that nearly reproduces in vivo-specific rates of protein synthesis and maintains them for at least 50 min. This procedure produced more than $0.4 \mathrm{mg} / \mathrm{mL}$ of aggregated human thrombopoietin polypeptide in a 1-hour reaction. The system offers simplicity and efficient use of reaction reagents and avoids the need to condense the cell extract and add exogenous T7 RNA polymerase. Curiously, the improved procedure preferentially synthesized $\beta$-lactamase from its native promoter rather than rDNA human growth hormone (hGH) from the tacII promoter even though more dilute reaction mixtures preferentially synthesized $\mathrm{hGH}$. Although this latter phenomenon is not currently understood, we believe that our improved batch procedure offers a simple, cost-effective and highly productive approach for in vitro protein synthesis.

\section{MATERIALS AND METHODS}

\section{Preparation of Cell Extract}

Cells from a 10-L fermentation of an $E$. coli K-12 triple-protease strain 27C7 (4) (degP, ompT, ptr-3) were harvested in mid-log phase and were immediately washed three times with S30 buffer (10 mM Tris-acetate, $\mathrm{pH} 8.2,14$ 
Table 1. Comparison of Improved System and Original System (15)

\begin{tabular}{|c|c|c|}
\hline Reagent & Improved System & Original System \\
\hline Tris-acetate & $56.4 \mathrm{mM}(\mathrm{pH} 8.2)$ & $35 \mathrm{mM}(\mathrm{pH} 8.0)$ \\
\hline DTT & $1.7 \mathrm{mM}$ & $2 \mathrm{mM}$ \\
\hline Sodium ATP & $2.9 \mathrm{mM}$ & $2 \mathrm{mM}$ \\
\hline Sodium CTP, GTP and UTP & $2.0 \mathrm{mM}$ & $0.5 \mathrm{mM}$ \\
\hline PEG-8000 & $5 \%$ & $3.5 \%$ \\
\hline Sodium PEP & $27 \mathrm{mM}$ & $20 \mathrm{mM}$ \\
\hline E. colitRNA & $0.17 \mathrm{mg} / \mathrm{mL}$ & $1 \mathrm{mg} / \mathrm{mL}$ \\
\hline Ammonium acetate & $36.0 \mathrm{mM}$ & $30 \mathrm{mM}$ \\
\hline Potassium acetate & $72.0 \mathrm{mM}$ & None \\
\hline Potassium glutamate & None & $190 \mathrm{mM}$ \\
\hline Magnesium acetate & $7.3 \mathrm{mM}$ & $8.0 \mathrm{mM}$ \\
\hline Folinic acid & $52 \mu \mathrm{g} / \mathrm{mL}$ & $20 \mu \mathrm{g} / \mathrm{mL}$ \\
\hline Folic acid & $2.7 \mu \mathrm{g} / \mathrm{mL}$ & None \\
\hline Pyridoxine- $\mathrm{HCl}$ & $2.7 \mu \mathrm{g} / \mathrm{mL}$ & None \\
\hline$\beta$-NADPa & $2.7 \mu \mathrm{g} / \mathrm{mL}$ & None \\
\hline$F A D^{b}$ & $2.7 \mu \mathrm{g} / \mathrm{mL}$ & None \\
\hline PABAC & $2.7 \mu \mathrm{g} / \mathrm{mL}$ & None \\
\hline cAMP & None & $1 \mathrm{mM}$ \\
\hline Methionine & $2 \mathrm{mM}$ & $0.3 \mu \mathrm{M}$ \\
\hline 19 amino acids & $0.56 \mathrm{mM}$ & $0.5 \mathrm{mM}$ \\
\hline IPTGd & $0.1 \mathrm{mM}$ & $0.8 \mathrm{~mm}$ \\
\hline $\begin{array}{l}\text { Cell extract (final protein } \\
\text { concentration) }\end{array}$ & $12 \mathrm{mg} / \mathrm{mL}$ (S135) & $7.9 \mathrm{mg} / \mathrm{mL}$ (S30) \\
\hline DNA & $0.26 \mu \mathrm{g} / \mu \mathrm{L}$ & $0.12 \mu \mathrm{g} / \mu \mathrm{L}$ \\
\hline \multicolumn{3}{|c|}{$\begin{array}{l}\text { aNicotinamide-adenine dinucleotide phosphate } \\
\text { bFlavin-adenine dinucleotide } \\
\text { cp-Aminobenzoic acid } \\
\text { d/sopropyl } \beta \text {-D-thiogalactopyranoside }\end{array}$} \\
\hline
\end{tabular}

$\mathrm{mM}$ magnesium acetate, $60 \mathrm{mM}$ potassium acetate and $1 \mathrm{mM}$ dithiothreitol [DTT]) (19) containing mercaptoethanol before freezing at $-80^{\circ} \mathrm{C}$. Frozen cells $(200 \mathrm{~g})$ were thawed at room temperature, resuspended thoroughly in $200 \mathrm{~mL}$ of S30 buffer using a tissue homogenizer and disrupted by passing twice through an M-110Y Microfluidizer $^{\circledR}$ (Microfluidics, Newton, MA, USA) at 10000 psi. Immediately, 10 $\mu \mathrm{L}$ of $1 \mathrm{M}$ DTT were added per $10 \mathrm{~mL}$ of lysate collected. The crude lysate was then processed according to published protocols (19) except that a final spin at $135000 \times g$ for 12 min was included in the protocol. This high-speed centrifugation removes small residual membrane particles from the cleared lysate (17). The lysate was separated into aliquots and frozen in liquid nitrogen for future use. The protein concentration of the lysate was measured by the Bradford assay (Bio-Rad, Hercules, CA, USA) with bovine serum albumin (BSA) as the standard. This cell extract is termed $\mathrm{S} 135$.

\section{Preparation of Plasmid DNA Templates}

Plasmid pMP331 (a kind gift from D. Yansura, Genentech) is a pBR322 derivative encoding for recombinant thrombopoietin (rTPO) driven from the trp promoter (6). Plasmid pRPHGH2 is a pUC19 derivative encoding for prerecombinant human growth hormone (pre-rhGH) driven from a strong tacII promoter (6). In addition, both plasmids encode for pre- $\beta$-lactamase driven from its natural promoter. Plasmids were purified from $250 \mathrm{~mL}$ of an overnight LB culture by first lysing the cells at $4^{\circ} \mathrm{C}$ in $25 \%$ sucrose, $50 \mathrm{mM}$ Tris- $\mathrm{HCl}(\mathrm{pH} 8.0)$ with $1.4 \mathrm{mg} / \mathrm{mL}$ hen egg white lysozyme, $55 \mathrm{mM}$ EDTA and $1 \%$ Triton ${ }^{\circledR} \mathrm{X}-100$. After centrifugation at $39000 \times g$ for $30 \mathrm{~min}, 2$ vol of $0.2 \mathrm{M} \mathrm{NaOH}, 1 \%$ sodium dodecyl sulfate (SDS) were added. After 5 min, 1 vol $2 \mathrm{M}$ potassium acetate, $2 \mathrm{M}$ acetic acid was added. The solution was clarified by centrifugation at $6800 \times g$ for 15 min and then precipitated at $-20^{\circ} \mathrm{C}$ for $1-2 \mathrm{~h}$ after adding $2 \mathrm{vol}$ of cold ethanol. The pellet was resuspended in $5 \mathrm{~mL}$ TE buffer (10 mM Tris-HCl, $1 \mathrm{mM}$ EDTA, $\mathrm{pH} 8.0$ ), adjusted to $2 \mathrm{M}$ ammonium acetate and incubated on ice for $20 \mathrm{~min}$. After centrifugation, the supernatant was again ethanol-precipitated and the pellet resuspended in $0.4 \mathrm{~mL}$ TE buffer for loading onto a Sepharose ${ }^{\circledR}$ CL 4B Gel Filtration Column (Amersham Pharmacia Biotech, Piscataway, NJ, USA). The column was equilibrated and eluted with TE buffer. Fractions were monitored for absorbance $(A)_{260} /$ $A_{280}$, and relevant fractions were examined by running on a $1 \%$ agarose gel. Fractions containing the plasmid and devoid of any contaminating RNA were pooled and concentrated for further use. This procedure of plasmid purification avoids RNase, phenol/chloroform and high concentrations of salts that might be detrimental to the performance of the in vitro system.

\section{Composition of In Vitro Transcription/Translation Systems}

The original in vitro system is essentially the same as that published by Lesley et al. (15) and derives from the landmark work of Zubay (27) and Pratt (19). One exception is that $12 \mu \mathrm{L}$ (rather than $15 \mu \mathrm{L}$ ) of S30 extract were added to give a final protein concentration of 7.9 $\mathrm{mg} / \mathrm{mL}$ in the $50-\mu \mathrm{L}$ reaction. The composition of the improved in vitro system described here is listed in Table 1 and compared to the original system. The composition in Table 1 does not, however, include the contribution of salts in the $\mathrm{S} 135$ or $\mathrm{S} 30$ cell extracts.

A typical $30-\mu \mathrm{L}$ reaction contained $10 \mu \mathrm{L} \mathrm{S135}$ cell extract, $3 \mu \mathrm{L}{ }^{35} \mathrm{~S}-\mathrm{me}$ thionine (Amersham Pharmacia Biotech), $7.5 \mu \mathrm{L}$ low-molecular-weight mixture, approximately $5 \mu \mathrm{L}$ plasmid DNA and the remainder was nucleasefree water. Transcription in this system is dependent on endogenous $E$. coli 


\section{Research Reports}

Table 2. Performance of the Improved System vs. a Commercial Kit for Synthesis of Human Thrombopoietin Using pMP331

\begin{tabular}{|c|c|c|c|c|c|}
\hline \multirow[t]{2}{*}{$\begin{array}{l}\text { In Vitro } \\
\text { System }\end{array}$} & \multirow[t]{2}{*}{$\begin{array}{l}\text { Protein in } \\
\text { Cell Extract } \\
(\mathrm{mg} / \mathrm{mL})\end{array}$} & \multicolumn{2}{|c|}{$\begin{array}{l}\text { Specific Protein } \\
\text { Synthesis Rate } \\
(\mu \mathrm{g} / \mathrm{mg} \text { protein } / \mathrm{h})\end{array}$} & \multicolumn{2}{|c|}{$\begin{array}{c}\text { Final Product } \\
\text { Concentration } \\
(\mu \mathrm{g} / \mathrm{mL})\end{array}$} \\
\hline & & pMP331 & pBEST/uc & pMP331 & pBEST/uc \\
\hline $\begin{array}{l}\text { Commercial } \\
\text { kit }\end{array}$ & 2.5 & 1.8 & 1.6 & 0.99 & 0.68 \\
\hline $\begin{array}{l}\text { Improved } \\
\text { system }\end{array}$ & 12.0 & 47.3 & ND & 466 & ND \\
\hline \multicolumn{6}{|c|}{$\begin{array}{l}\text { ND: not determined. pBEST/uc was supplied by the kit manufacturer as a posi- } \\
\text { tive control. }\end{array}$} \\
\hline
\end{tabular}

RNA polymerase. All chemicals were purchased from Sigma Chemical (St. Louis, MO, USA) except tRNA (Boehringer Mannheim, Indianapolis, IN, USA) and phosphoenol pyruvate (PEP; Fluka Chemical, Ronkonkoma, NY, USA).

\section{Monitoring ${ }^{35} \mathrm{~S}-$ Methionine Incorporation}

In vitro transcription/translation was initiated by adding plasmid DNA to the reaction mixture at $37^{\circ} \mathrm{C}$. Small aliquots $(3-5 \mu \mathrm{L})$ were withdrawn at indicated time points and spotted on Whatman GF/C Filter Paper (Clifton, NJ, USA). These were dried for $30 \mathrm{~min}$ at room temperature, soaked in cold methanol containing $10 \%$ trichloroacetic acid (TCA) and $0.1 \%$ cold methionine for $1 \mathrm{~h}$ and soaked again for 30 min in cold methanol with 5\% TCA and $0.1 \%$ methionine. Finally, the filter papers were washed for $5 \mathrm{~min}$ in acetone and dried for $2 \mathrm{~h}$ at room temperature. Radioactivity was determined using $5 \mathrm{~mL}$ of scintillation cocktail. Counts per minute (cpm) were measured twice and the results averaged. The cpm of unwashed samples from the reaction were measured to determine the specific activity of ${ }^{35} \mathrm{~S}$-methionine in the reaction mixture.

\section{Calculation of Specific Protein Synthesis Rate}

To calculate the specific synthesis rate $(\mu \mathrm{g}$ new protein/mg total cell protein/h), the specific radioactivity of the methionine (hot and cold) used in the reaction was calculated by dividing the measured radioactivity of unwashed samples by the known concentration of methionine. The cpm of TCA-precipitated and washed samples were then used to determine the amount of methionine incorporated into protein. The measured cpm of samples from complete reaction mixtures were corrected for background by subtracting the corresponding time point $\mathrm{cpm}$ of reactions without plasmid DNA. The corrected cpm were used to estimate protein synthesis rates, and these were divided by the protein content of the cell extracts to determine specific expression rates.

\section{SDS Polyacrylamide Gel Electrophoresis (PAGE)}

Samples were withdrawn at the end of an in vitro reaction, mixed with equal volumes of $2 \times$ tricine buffer (NOVEX, San Diego, CA, USA), boiled for $5 \mathrm{~min}$ and loaded onto a 10\%-20\% tricine gel (NOVEX). ${ }^{14} \mathrm{C}$ standard markers (Amersham Pharmacia Biotech) were run in one of the wells. Gels were fixed for 30 min in $500 \mathrm{~mL}$ of $34.6 \mathrm{~g} / \mathrm{L}$ sulphosalicylic acid and $115 \mathrm{~g} / \mathrm{L} \mathrm{TCA}$, treated for $30 \mathrm{~min}$ each in gel-drying solution (NOVEX) and $1 \mathrm{M}$ sodium salicylate, $0.1 \mathrm{~N} \mathrm{NaOH}$ before drying for $2 \mathrm{~h}$ in a gel dryer. Dried gels were exposed to X-OMAT Film (Scientific Imaging Systems [Eastman Kodak], Rochester, $\mathrm{NY}, \mathrm{USA}$ ) at $-70^{\circ} \mathrm{C}$ for $1-12 \mathrm{~h}$ to detect ${ }^{35} \mathrm{~S}$-labeled translation products.

\section{RESULTS AND DISCUSSION}

Following an extensive investigation of various parameters in our laboratory by Amina Sheikh, the initial specific rate of protein production for the original in vitro system of Pratt (19) and Zubay (27) was increased substantially to approximate in vivo rates of recombinant protein production. Details of this experimentation will be published elsewhere, but the main differences are shown in Table 1. The biggest advantage was gained from increasing the methionine concentration (42-fold improvement in rate) but adjusting the concentration of the DNA (8-fold improvement) and polyethylene glycol (PEG)-8000 (1.5-fold improvement), and low-molecular-weight translation initiation factors (1.5-fold improvement) also contributed.

This initial investigation was conducted using a T7 promoter for expression of pre-rhGH. When promoters recognized by native $E$. coli RNA polymerase were used, the duration of methionine incorporation was limited to approximately $30 \mathrm{~min}$. We observed substantial precipitation in the reaction mixture after $15 \mathrm{~min}$. Further efforts revealed that $\mathrm{Ca}^{++}(9.7 \mathrm{mM})$ was the source of this precipitation. Removal of calcium extended the period of protein synthesis to at least $50 \mathrm{~min}$. It is of interest that the in vivo concentration of free calcium in $E$. coli is negligible $(8,16)$. Many existing in vitro systems contain calcium in millimolar concentrations, and apparently that poses no problem $(1,9,13,19,27)$. In fact, it might even be beneficial for relatively dilute systems using the T7 or SP6 RNA polymerases. However, as we seek to use the native RNA polymerase as well as higher concentrations of key components, calcium becomes detrimental.

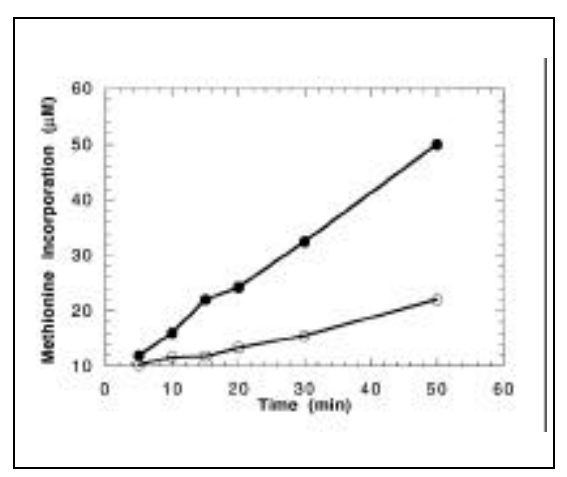

Figure 1. Time course of methionine incorporation while expressing TPO from a trp promoter with the improved system. Open circles denote methionine incorporation without the addition of plasmid DNA, and closed circles indicate results from reactions with the addition of pMP331. 
Table 3. Performance of the Improved System vs. the Original System (15) for Protein Synthesis from pRPHGH2 Encoding for Pre- $\beta$-Lactamase from its Native Promoter and for Pre-rhGH from the tacII Promoter

\begin{tabular}{|c|c|c|c|c|}
\hline \multirow[t]{2}{*}{$\begin{array}{l}\text { In Vitro } \\
\text { System }\end{array}$} & \multirow[t]{2}{*}{$\begin{array}{l}\text { Protein in } \\
\text { Cell Extract } \\
(\mathrm{mg} / \mathrm{mL})\end{array}$} & \multirow[t]{2}{*}{$\begin{array}{l}\text { Specific Protein } \\
\text { Synthesis Rate } \\
(\mu \mathrm{g} / \mathrm{mg} \text { protein } / \mathrm{h})\end{array}$} & \multicolumn{2}{|c|}{$\begin{array}{c}\text { Final Product } \\
\text { Concentration } \\
(\mu \mathrm{g} / \mathrm{mL})\end{array}$} \\
\hline & & & pre-rhGH & pre- $\beta$-lactamase \\
\hline $\begin{array}{l}\text { Original } \\
\text { system }\end{array}$ & 7.9 & 0.009 & 0.04 & negligible \\
\hline $\begin{array}{c}\text { Improved } \\
\text { system }\end{array}$ & 12.0 & 9.38 & low & 94 \\
\hline
\end{tabular}

To test the improved method with a different promoter and product, we used plasmid pMP331 encoding the heterologous protein rTPO, driven from a trp promoter. The protein yield was compared to that of a commercially available in vitro protein synthesis system. Figure 1 shows the time course of methionine incorporation for the improved system as measured by TCAprecipitable cpm. Methionine incorporation is linear for at least $50 \mathrm{~min}$. The high background of methionine incorporation without plasmid addition is probably due to background transcription/translation from chromosomal DNA in the cell extract. This back-

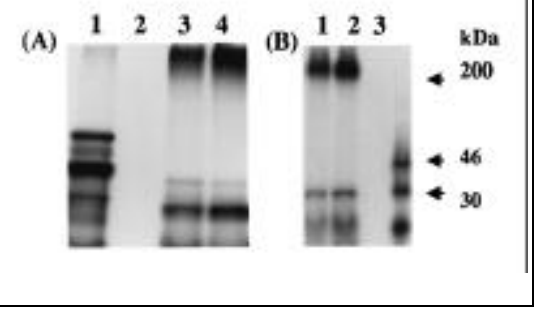

Figure 2. Fluorograms of gels showing products synthesized from pMP331 with the commercial kit (A) and the improved system (B). 5 $\mu \mathrm{L}$ of sample were withdrawn after a 50-min reaction (Figure 1) and boiled for $5 \mathrm{~min}$ with equal volumes of $2 \times$ tricine buffer before loading on to $10 \%-20 \%$ tricine gels. Gels were dried and processed for fluorography as described in Materials and Methods. The relative intensity of bands on these fluorograms does not correlate with quantitative estimates of proteins synthesized because the specific activity of ${ }^{35} \mathrm{~S}$-methionine used is different in each system. (A) Lane 1 shows results with the positive control plasmid pBESTluc supplied with the commercial kit. Lane 2 is a control without plasmid, and lanes 3 and 4 are two independent reactions with plasmid pMP331. (B) Lanes 1 and 2 represent the results of two independent reactions with plasmid pMP331. Lane 3 shows results without plasmid addition. ground was subtracted in determining rTPO expression rates and yields.

With the E. coli S30 Extract System for Circular DNA (Promega, Madison, WI, USA), methionine incorporation into rTPO is essentially complete after 10 min (data not shown). This short burst of incorporation was also observed with the positive control DNA $\left(\mathrm{pBEST} l u c^{\mathrm{TM}}\right)$ supplied with the kit. Specific synthesis rates and protein yields for the two systems are shown in Table 2. For calculation purposes, it is assumed that either rTPO or luciferase is the major protein product. This assumption is supported by the fluorograms shown in Figure 2. Faster rates and prolonged synthesis result in nearly a 500-fold increase in protein accumulation with the improved system. It is gratifying that conditions identified with the T7 promoter/pre-rhGH system provide excellent results with the trp promoter/rTPO plasmid. It is also relevant that both the rTPO and luciferase plasmids produced similar results with the commercial kit.

Figure 2, A and B, shows the fluorograms of samples from rTPO expression reactions run on $10 \%-20 \%$ tricine polyacrylamide gels. These results indicate that the major species in both in vitro systems is aggregated rTPO that migrates at the top of the gel at around $200 \mathrm{kDa}$. The identity of this band was confirmed by Western blotting. A minor amount of pre- $\beta$-lactamase is also made in both systems and migrates at around $31 \mathrm{kDa}$. Monomeric rTPO (37.5 $\mathrm{kDa}$ accumulates in insignificant amounts. rTPO aggregates $(200 \mathrm{kDa})$ are also the major species when rTPO is expressed in vivo in $E$. coli from the same plasmid construct (personal com- 
munication from D. Reilly, Genentech). Estimated in vivo rTPO accumulation rates are approximately $17 \mu \mathrm{g} / \mathrm{mg}$ cell protein/h. Thus, our improved system not only produces a polypeptide similar to that observed in vivo but also is capable of exceeding estimated in vivospecific accumulation rates.

To compare our improved system to an in vitro system from the literature (15), we expressed pre-rhGH from a tacII promoter using plasmid pRPH$\mathrm{GH} 2$. Time courses of methionine incorporation as monitored by TCA-precipitable cpm are shown in Figure 3, A and B. Both the original and the improved systems showed linear rates of protein synthesis for at least $50 \mathrm{~min}$. However, the ordinates have different scales because the quantities of methionine incorporated were significantly different between the two systems.

Figure 4, A and B, shows fluorograms of gels showing the products synthesized in the two in vitro reaction systems. To our surprise, the improved system synthesized predominantly pre$\beta$-lactamase $(31 \mathrm{kDa})$ while the original system synthesized pre-rhGH (22 $\mathrm{kDa})$ as the major species. The identity

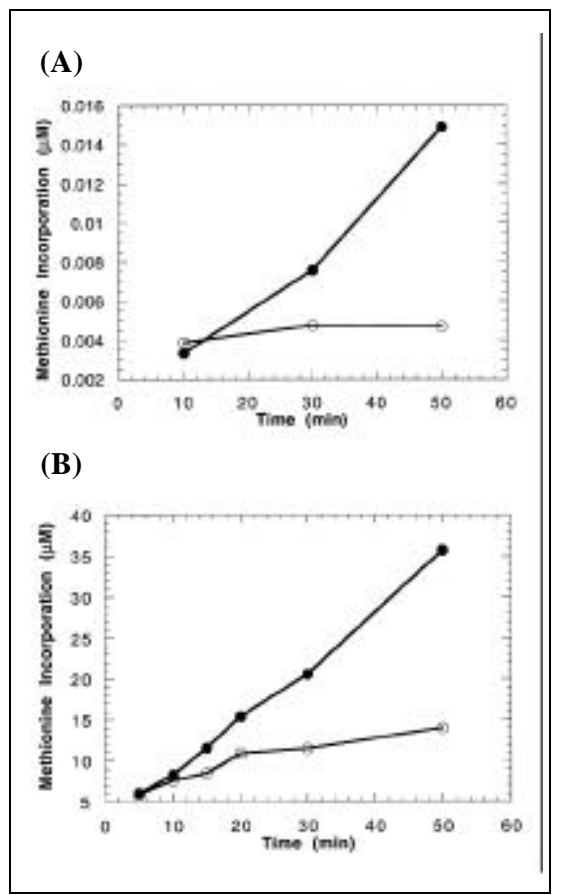

Figure 3. Time course of ${ }^{35} \mathrm{~S}$-methionine incorporation with pRPHGH2 using the original method (A) and improved system (B). Plot symbols are as described for Figure 1. of the pre-rhGH was confirmed by Western blotting (not shown).

Quantitative results are shown in Table 3. The specific rate of protein production in the original system is $0.009 \mu \mathrm{g}$ pre-rhGH/mg cell protein $/ \mathrm{h}$, while the improved system yields a rate of $9.34 \mu \mathrm{g}$ pre- $\beta$-lactamase $/ \mathrm{mg}$ cell protein/h. The estimated in vivo-specific rate for $\mathrm{rhGH}$ is $12-19 \mu \mathrm{g} / \mathrm{mg}$ protein/h (3). Although it was encouraging that $94 \mu \mathrm{g} / \mathrm{mL}$ of pre- $\beta$-lactamase were made with a promoter that is relatively weak in vivo, it was disappointing that rhGH expression was so low from a promoter that is much stronger (tacII) (Figure 4B). The significant accumulation of pre- $\beta$-lactamase suggests that the in vitro transcription and translation reactions are working well. It is not clear at this stage whether the low prerhGH accumulation is attributable to weak recognition of the tacII promoter by the native $E$. coli RNA polymerase in our in vitro environment or is related to the stability of rhGH messenger RNA or, perhaps, the stability of the polypeptide. Until this is known, we would recommend the use of the trp rather than the tacII promoter.

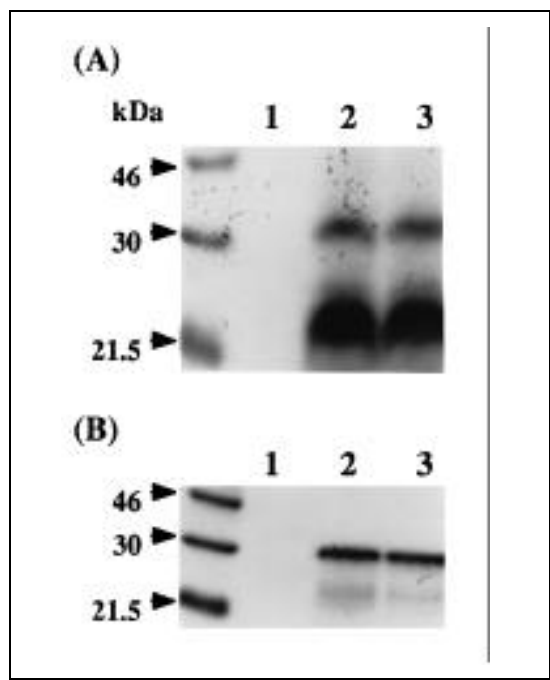

Figure 4. Fluorograms of gels showing different products synthesized from PRPHGH2 in the original (A) and improved systems (B). Lane 1 is a control with no plasmid and lanes 2 and 3 represent two independent reactions with plasmid pRPHGH2. Samples were processed as described for Figure 2. Again, relative intensity of bands on these fluorograms does not correlate with quantitative estimates of proteins synthesized because the specific activity of ${ }^{35} \mathrm{~S}$-methionine used is different in each system. 
In summary, we have developed an E. coli-based, in vitro protein synthesis system that reproduces in vivo-specific rates of heterologous protein synthesis. Specific rates of protein synthesis are 1000-fold higher than with the literature system used for comparison. The volumetric yields are also quite high, exceeding those of a commercially available batch system by more than two orders of magnitude. It is worth noting that the in vivo-specific rate of total protein synthesis for $E$. coli growing with a doubling time of $30 \mathrm{~min}$ is approximately $1.7 \mathrm{mg} / \mathrm{mg}$ soluble protein/h, considerably higher than the rate we have achieved in vitro and also much higher than the in vivo-specific expression rates for most heterologous proteins.

As a batch, coupled transcription/translation system with intrinsic ATP/ GTP regeneration, our improved system offers simple operation. Also, the consumption of reagents such as amino acids and nucleotides is significantly reduced relative to published continuous in vitro systems $(1,23)$ and is also lower than for the published semicontinuous system (10). We believe that our improved system can be scaled easily to larger volumes and offers significant advantages for the production of research proteins. In addition, approximate duplication of in vivo-specific rates of protein production is the first step towards developing an E. colibased coupled transcription/translation system that mimics in vivo physiology. Other biochemical attributes of the cytoplasm, such as macromolecular crowding $(25,26)$, ionic composition ( 2 , $14,20,21)$ and state of the plasmid DNA etc., also need to be considered in the search for true cytoplasmic replication.

\section{ACKNOWLEDGMENTS}

We thank Dot Reilly for sharing her data on in vivo expression of rTPO in E. coli. Antibodies for rhGH and rTPO were obtained from Jennifer Gaunce and Sylvia Wong, respectively; we acknowledge their help. Technical assistance provided by Susan Leung on fermentation procedures is highly appreciated. Lastly, we thank Brad Snedecor, Nancy McFarland and John Joly for stimulating discussions.

\section{REFERENCES}

1.Baranov, V.I., I.Y. Morozov, S.A. Ortlepp and A.S. Spirin. 1989. Gene expression in a cell-free system on the preparative scale. Gene 84:463-466.

2.Cayley, S., B.A. Lewis, H.J. Guttman and M.T. Record, Jr. 1991. Characterization of the cytoplasm of Escherichia coli K-12 as a function of external osmolarity. J. Mol. Biol. 222:281-300.

3.Chang, C.N., M. Rey, B. Bochner, H. Heyneker and G. Gray. 1987. High-level secretion of human growth hormone by Escherichia coli. Gene 55:189-196.

4.Chang, J.Y., N.C. McFarland and J.R. Swartz, inventors. Genentech, assignee. Method for Refolding Insoluble, Misfolded Insulin-Like Growth Factor-I into an Active Conformation. US patent 5,288,931. 1994 February 22.

5.Davis, J., D. Thompson and G.S. Beckler. 1996. In vitro Transcription/Translation. Large Scale Dialysis Reactions Using E. coli S30 Extract Systems. Promega Notes 56:1421.

6.de Boer, H.A., L.J. Comstock and M. Vasser. 1983. The tac promoter: a functional hybrid derived from the trp and lac promoters. Proc. Natl. Acad. Sci. USA 80:21-25.

7.Ellman, J., D. Mendel, S. Anthony-Cahill, C.J. Noren and P.G. Schultz. 1991. Biosynthetic method for introducing unnatural amino acids site-specifically into proteins, p. 301336. In J.J. Langone (Ed.), Methods in Enzymology, Vol. 202. Academic Press, New York.

8.Gangola, P. and B.P. Rosen. 1987. Maintenance of intracellular calcium in Escherichia coli. J. Biol. Chem. 262:12570-12574.

9.Kigawa, T. and S. Yokoyama. 1991. A continuous cell-free protein synthesis system for coupled transcription-translation. J. Biochem. (Tokyo) 110:166-168.

10.Kim, D.-M. and C.-Y. Choi. 1996. A semicontinuous prokaryotic coupled transcription/translation system using a dialysis membrane. Biotechnol. Prog. 12:645-649.

11.Kim, D.-M., T. Kigawa, C.-Y. Choi and S. Yokoyama. 1996. A highly efficient cell-free protein synthesis system from Escherichia coli. Eur. J. Biochem. 239:881-886.

12.Kudlicki, W., G. Kramer and B. Hardesty. 1992. High efficiency cell-free synthesis of proteins: refinement of the coupled transcription/translation system. Anal. Biochem. 206:389-393.

13.Kudlicki, W., M. Mouat, J.P. Walterscheid, G. Kramer and B. Hardesty. 1994. Development of a chaperone-deficient system by fractionation of a prokaryotic coupled transcription/translation system. Anal. Biochem. 217:12-19.

14.Leirmo, S., C. Harrison, D.S. Cayley, R.R. Burgess and M.T. Record, Jr. 1987. Replacement of potassium chloride by potassium glutamate dramatically enhances proteinDNA interactions in vitro. Biochemistry 26:2095-2101.

15.Lesley, S.A., M.A.D. Brow and R.R. Burgess. 1991. Use of in vitro protein synthesis from polymerase chain reaction-generated templates to study interaction of Escherichia coli transcription factors with core RNA polymerase and for epitope mapping of monoclonal antibodies. J. Biol. Chem. 266:2632-2638.

16.Liguri, G., C. Cecchi, A. Pieri, G. Raugei, M. Vecchi, A. Modesti, P. Nassi and G. Ramponi. 1994. Expression of human acylphosphatase in Escherichia coli affects intracellular calcium levels. Biochem. Mol. Biol. Int. 34:109-117.

17.Muller, M. and G. Blobel. 1984. In vitro translocation of bacterial proteins across the plasma membrane of Escherichia coli. Proc. Natl. Acad. Sci. USA 81:7421-7425.

18.Nishimura, N., Y. Kitaoka and M. Niwano. 1995. Cell-free system derived from heatshocked Escherichia coli. Synthesis of enzyme protein possessing higher specific activity. J. Fermentation Bioeng. 79:131-135.

19.Pratt, J.M. 1984. Coupled transcriptiontranslation in prokaryotic cell-free systems, $\mathrm{p}$. 179-209. In B.D. Hames and S.J. Higgins (Ed.), Transcription and Translation, A Practical Approach. IRL Press, Oxford.

20.Richey, B., D.S. Cayley, M.C. Mossing, C. Kolka, C.F. Anderson, T.C. Farrar and M.T. Record, Jr. 1987. Variability of the intracellular ionic environment of Escherichia coli. J. Biol. Chem. 262:7157-7164.

21.Roe, J.H. and M.T. Record, Jr. 1985. Regulation of the kinetics of the interaction of $E s$ cherichia coli RNA polymerase with the lambda $\mathrm{P}_{\mathrm{R}}$ promoter by salt concentration. Biochemistry 24:4721-4726.

22.Spirin, S.A., V.I. Baranov, L.A. Ryabova, S.Y. Ovodov and Y.B. Alakhov. 1988. A continuous cell-free translation system capable of producing polypeptides in high yield. Science 242:1162-1164.

23.Stiege, W. and V.A. Erdmann. 1995. The potentials of the in vitro protein biosynthesis system. J. Biotechnol. 41:81-90.

24. Yamane, T., Y. Kawarasaki and H. Nakano. 1995. In vitro protein biosynthesis using ribosome and foreign mRNA. An approach to construct a protein biosynthesizer. Ann. NY Acad. Sci. 750:146-157.

25.Zimmerman, S.B. and A.P. Minton. 1993. Macromolecular crowding: biochemical, biophysical, and physiological consequences. Annu. Rev. Biophys. Biomol. Struct. 22:2765.

26.Zimmerman, S.B. and S.O. Trach. 1991. Estimation of macromolecule concentrations and excluded volume effects for the cytoplasm of Escherichia coli. J. Mol. Biol. 222:599620 .

27.Zubay, G. 1973. In vitro synthesis of protein in microbial system. Annu. Rev. Genet. 7:267287.

Received 19 May 1997; accepted 31 December 1997.

Address correspondence to:

Dr. James R. Swartz

MS \#32, Genentech, Inc.

460 Pt. San Bruno Blvd.

S. San Francisco, CA 94080, USA

Internet: swartz.jim@gene.com 